\title{
WTO ACCESSION OF BRICS COUNTRIES: THE CHINESE EXPERIENCE
}

\author{
IRINA MIKHEEVA, \\ National Research University Higher School of Economics \\ (Nizhny Novgorod, Russia) \\ ANASTASIA LOGINOVA, \\ National Research University Higher School of Economics \\ (Nizhny Novgorod, Russia)
}

DOI: $10.21684 / 2412-2343-2017-4-1-84-99$

The stages of reforms under the influence of requirements of the World Trade Organization are considered on the basis of an analysis of Chinese legislation. Four stages of preparation by the People's Republic of China for accession to the WTO within which there was a transformation of the legal system of China from 1982 to 2001 are described. The sources of Chinese lawmaking are presented and systematized as the basis of the economic legislation of the PRC at the stage of preparation for inclusion of China in the WTO. Attention is drawn to the particularities of the power organization of the Chinese state, in which there is no separation of powers into three branches: legislative, executive and judicial. This, in turn, allows to mark the feature in the economic sphere of legal regulation in China connected with the existence of the rules established by the Supreme National Court as a source of law. To represent the dynamics of normativelegal regulation of foreign trade activities, China has used the system of dialectical and universal methods of knowledge; general scientific methods (induction and deduction) and techniques (analysis and synthesis); as well as a special method - formally-legal. The identified course and direction of changes in legal support of domestic and foreign economic processes in China suggests the possibility to consider the experience of China in the promotion of Russia in the international trading community.

The authors propose that the entry of China into the WTO is of interest to the BRICS countries as long as China achieves optimal utilization of the WTO's external economic opportunities. In addition, China has established a legally solid basis for the development of market relations in the state. 
Keywords: China; national legislation; WTO accession; market economy; foreign trade activity.

Recommended citation: Irina Mikheeva \& Anastasia Loginova, WTO Accession of BRICS Countries: The Chinese Experience, 4(1) BRICS Law Journal 84-99 (2017).

\section{Introduction}

China's entry into the World Trade Organization (WTO) on December 11, 2001 marked the beginning of a new era of economic development and global changes in the economic and social life of the country. To meet accession requirements, China had to accept a broad range of obligations and this influenced the legal regulation of the most important spheres of the country's life. China's integration into the international trade system required economic changes and the transformation of legal support of reform processes. The history of China's accession to the WTO reflects the stages of reform of national legislation in accordance with international trade cooperation requirements.

\section{Stages of China's Entry into the WTO}

The beginning of China's entry into the international trading community occurred with the signing of the General Agreement on Tariffs and Trade (GATT) on October 30, 1947 by the Kuomintang Government to become a member, along with twentythree other countries, of GATT/WTO.' The People's Republic of China (PRC) began participation in GATT/WTO bodies as an observer (without a right to vote) only in 1982. At this time the priority was given to the formulation of program documents in which the course and direction of further economic development were defined and the specific priority of Chinese economic growth objectives was listed. In the sphere of innovation, this relates to the PRC's Science and Technology Development Program for 1978-1985 and Program 863.

A number of laws and regulations were passed and put into effect. To widen the exchange of engineering information with other countries and to advance international economic cooperation, the PRC adopted the Act "On Joint Chinese and Foreign Companies Limited by Shares" at the Second Session of the National People's

\footnotetext{
Up to 1949 , China was represented in GATT by the Kuomintang Government. After the founding of the PRC in 1949 the new government was absent from GATT participation, though never withdrawing its claim to status as an original contracting party to the agreement. In 1986, China decided to resume a position in GATT and obtained the status of observer. When first applying for accession to GATT, China hoped for automatic (unconditional) restoration of membership in the organization. But, all together, the negotiation process with GATT/WTO lasted 15 years (1986-2001).
} 
Congress (NPC) of the $5^{\text {th }}$ Convocation held on July 1, 1979. As per this Act, foreign companies, enterprises and other market participants (both legal entities and natural persons) are allowed to establish and enter into joint national ventures in China upon authorization by the Chinese government. The Act stipulated the obligation of the Chinese government to protect the economic rights of foreign members of joint ventures in general and in respect of investments and profit share in particular, all of which was required to be set down in articles of association, contracts and agreements subject to compulsory approval by the Chinese government.

This stage (first period, 1947-1982) was necessary for preparation by China to become a member of the world economic community and subject of international economic and legal regulations. The adoption at this time of legislative acts with economic content by the Chinese government was aimed at the liberalization of foreign trade and foreign economic activity in order to improve China's path to accession to the WTO.

Starting in the early 1980s we can note the following stage of movement by the PRC towards WTO membership (second period, 1982-1987). The admission of the PRC in 1982 to GATT without a right to vote was accompanied by new requirements for China. These requirements related to access for American service companies to the Chinese market and thus also directly related to domestic policy issues of China development. In order to resolve the situation, the number of Chinese GATT/WTO negotiation members had to be increased. If only the Ministry of Foreign Trade and Economic Cooperation together with the Customs Committee participated in negotiations at the start, in 1982-1987 other interested bodies and agencies joined in as needed. ${ }^{2}$ The general public had almost no information on the process of negotiations on GATT/WTO accession.

Simultaneously, Chinese economic legislation (laws and regulations) was aligned with the prospects of development of the market economy in the country. In 1983, to ensure implementation arrangements of PRC Act "On Joint Chinese and Foreign Companies Limited by Shares" (1982), the State Council of the PRC published the decree "On Application of PRC Act on Joint Chinese and Foreign Companies Limited by Shares" (September 20, 1982). The decree stipulated the procedures for the establishment and registration of joint ventures, legal forms and authorized capital, methods of authorized capital payment, management bodies, and application of technologies, land allocation rights, purchase and sale, taxation, currency control, fiscal bookkeeping, employment, trade unions, duration of activity and liquidation procedures and dispute settlement. ${ }^{3}$

Liang Wei, China's WTO Negotiation Process and Its Implications, 11(33) Journal of Contemporary China 683-719 (2002).

3 Later these regulatory acts were amended (January 15, 1986, December 21, 1987, June 22, 2001, January 8, 2011, February 19, 2014) (Feb. 25, 2017), available at http://pavel.bazhanov.pro/translations/ chinaeconomiclaw/china_sino_foreign_equity_enterprise_implementation/. 
Almost simultaneously with this decree, the State Council adopted and approved "Rules of Registration and Regulation of Activity of Permanent Representations of Foreign Companies in the PRC."These rules were published by the Central Office of the PRC Commerce and Industry Administration in $1983 .{ }^{4}$

"General Provisions of Civil Legislation of the PRC" and PRC Act "On Companies with Foreign Capital" were signed at the Fourth Session of the National People's Congress of the $6^{\text {th }}$ Convocation held on April 12, 1986 to "regulate civil relations due to requirements on development of social modernization... and taking the real national situation into account." One section of the "General Provisions" was dedicated to the application of legislation in civil relations of China with the rest of the world. ${ }^{5}$

From the standpoint of legal support of the development of the national economy, PRC Act"On Companies with Foreign Capital" (latest edition, 2000) is of interest. By this Act the PRC gave impulse to the development of the Chinese economy and added one more step to the deepening and widening of foreign economic cooperation, including in fields relating to engineering. A concrete result was that foreign investors (companies and other business units or natural persons) were given an opportunity to establish companies in China through the use of foreign capital.

At this stage, then, China shifted from permission to establish joint companies limited by shares, to the opening up of the opportunity to establish companies fully based on a foreign investor's capital. A fundamental condition for establishing such companies was an obligation to a positive influence on the development of the national economy of the PRC. Priority was to be given to companies with foreign capital that applied state of-the-art technologies and exported products.

The PRC Customs Code was adopted at the Nineteenth Session of the Permanent Council of the National People's Congress (NPC) of the $6^{\text {th }}$ Convocation held the next year on January 22, 1987. The Code marked one of the crucial turns of direction in the modernization of the economic development of China - the "facilitation of foreign economic ties in commerce, research and development and cultural exchange."

4 Today this document is invalid due to adoption of a new one in 2011 which stipulates the procedure for accreditation, registration of changes and liquidations of representative offices of foreign companies Directive "On Registration of Representative Offices of Foreign Companies" (Order of PRC State Council No. 584). This new document became the basic legal act that determines the procedure for the establishment of representative offices of foreign companies in China and the procedure for registration, alteration of registration and annulment of registration (Feb. 25, 2017), available at http://pavel.bazhanov. pro/books_publications/publications/representative_office_registration_new_rules_2011/.

5 General provisions of PRC Civil Law, adopted at the Fourth Session of the National People's Congress of the $6^{\text {th }}$ Convocation held on April 12, 1986 (Feb. 25, 2017), available at http://chinalawinfo.ru/ civil_law/general_principles_civil_law.

6 PRC Customs Code, adopted at the Nineteenth Session of the Permanent Council of the National People's Congress of the $6^{\text {th }}$ Convocation held on January 22, 1987, amended under Directive "On Amendment of the 'Customs Code of the People's Republic of China"', adopted at the Sixteenth Session of the Permanent Council of the National People's Congress of the $9^{\text {th }}$ Convocation held on July 8, 2000 (Feb. 25, 2017), available at http://chinalawinfo.ru/economic_law/law_customs/law_customs_ch1. 
China's desire to join the WTO engaged with the necessity to harmonize national legislation with WTO requirements and to align legislation with international norms of market economy countries. That is why the first articles of many legal acts adopted at the WTO accession preparation stage contained the following purpose of legal regulation - assistance in market economy development.

A GATT working group to study China's WTO accession application was created in 1987, and this started long and complicated negotiations on China's accession to the WTO, and it also helps to identify the third stage of this process.

During this (third) period in China's process of accession to the WTO (1988-1994) (up until GATT became the WTO) there were nineteen meetings of the GATT working group on China's accession. As a result of the actions of the Chinese government on June 4, 1989 in putting down the pro-democracy protests in Tiananmen Square, the hardline stance of Western countries against China's accession complicated the negotiation process. Shortly afterwards, in 1990, within the scope of the meetings of the working group there followed discussions on the economic policy of the PRC. In 1993, China presented its version of the Memorandum on National Foreign Trade System.

It should be pointed out that to hasten its accession to GATT by the end of 1994 China fulfilled almost all requirements. These requirements related to, among others, the creation of a unified taxation system and a unified floating national currency exchange rate, the decrease in the direct planning of foreign trade, the decrease in the number of goods for compulsory licensing and quota allocation, and the canceling of direct export subventions.

Economic legislation was improved in the second half of the 1980s to the beginning of the 1990s. PRC Act "On Cooperation Joint Ventures of Chinese and Foreign Capital" ${ }^{\prime \prime}$ was adopted at the First Session of the NPC of the $7^{\text {th }}$ Convocation held on April 12, 1998. The purpose of the Act was to broaden economic cooperation and the exchange of engineering information with foreign countries. This Act defined the general requirements for the establishment of joint ventures in the PRC based upon the mutual participation of Chinese and foreign companies (cooperation companies). Cooperation joint ventures in the PRC became an alternative to the joint company limited by shares or a company with 100 percent foreign capital. ${ }^{8}$

7 PRC Act "On Contractual Joint Chinese and Foreign Ventures" amended under Decision "On Amendment of PRC Act 'On Contractual Joint Chinese and Foreign Ventures"' at the Eighteenth Session of the Permanent Council of the National People's Congress of the $9^{\text {th }}$ Convocation held on October 31, 2000.

8 PRC Act "On Cooperation Joint Ventures of Chinese and Foreign Capital" adopted at the Second Session of the National People's Congress of the $5^{\text {th }}$ Convocation held on July 1, 1979; amended by Decision "On Amendment of PRC Act'On Joint Chinese and Foreign Capital Ventures Limited by Shares'"taken at the Third Session of the National People's Congress of the $7^{\text {th }}$ Convocation held on April 4, 1990; amended by Decision "On Amendment of PRC Act 'On Joint Chinese and Foreign Capital Ventures Limited by Shares"' taken at the Fourth Session of the National People's Congress of the $9^{\text {th }}$ Convocation held on March 15, 2001 (Feb. 25, 2017), available at http://chinalawinfo.ru/economic_law/law_equity_joint. 
Together with the new laws previously adopted, Acts were modified in accordance with the necessity to take into account the development of a market economy in China. PRC Act "On Joint Chinese and Foreign Companies Limited by Shares" was amended in 1990 to widen international economic cooperation and the exchange of engineering information in the PRC. Decree "On Application of PRC Act on Joint Chinese and Foreign Companies Limited by Shares" ${ }^{\prime \prime}$ was also amended. Implementation arrangements in respect of the Act "On Joint Chinese and Foreign Companies Limited by Shares" were amended by Temporary Direction "On the Duration of Activities of Joint Chinese and Foreign Companies Limited by Shares" (1990). This Temporary Direction was aimed to determine cases where joint companies limited by shares should or should not set a time-limit on their activities.

On the way to a market economy it was important to normalize the establishment and activities of companies and to support the legal rights and interests of the companies, members (shareholders), and creditors. For this purpose, PRC Act "On Companies"10 was adopted in 1993. This Act regulated the establishment in the PRC of limited liability companies and joint-stock limited liability companies. These legal forms are the most requested for business activity in today's China.

The implementation arrangements of this Act were set forth in Directive "On Registration of Authorized Capital of Companies" that referred to authorized capital and payment of shares in authorized capital. Later, in 2004, the business profile of companies was clarified by Direction "On Registration of Corporate Business Profile"11 and rules for registration of the establishment, changes and annulment of registration, due to being struck off the Business Register (limited liability companies and joint-stock limited liability companies) were detailed in Directive "On Business Registration."12

9 Decision "On Amendment of PRC Act 'On Joint Chinese and Foreign Capital Ventures Limited by Shares"' taken at the Third Session of the National People's Congress of the $7^{\text {th }}$ Convocation held on April 4, 1990 (Feb. 25, 2017), available at http://chinalawinfo.ru/economic_law/law_equity_joint.

10 PRC Act "On Companies" adopted at the Fifth Session of the Permanent Council of the National People's Congress of the $8^{\text {th }}$ Convocation held on December 29, 1993; first amendment was made by Decision "On Amendment of PRC Act 'On Companies"' taken at the Thirteenth Session of the Permanent Council of the National People's Congress of the $9^{\text {th }}$ Convocation held on December 25, 1999; second amendment was made by Decision "On Amendment of PRC Act 'On Companies"' taken at the Eleventh Session of the Permanent Council of the National People's Congress of the $10^{\text {th }}$ Convocation held on August 28, 2004; edited by Decision of the Eighteenth Session of the Permanent Council of the National People's Congress of the $10^{\text {th }}$ Convocation held on October 27, 2005 (Feb. 25, 2017), available at http://chinalawinfo.ru/economic_law/law_company.

11 Order of Central Government Office of Commerce and Industry Administration of the People's Republic of China, No. 14-2004 (Feb. 25, 2017), available at http://pavel.bazhanov.pro/translations/ chinacivillaw/china_enterprise_business_scope/.

12 Directive"On Registration of Companies" (edited February 19, 2014) (Feb. 25, 2017), available at http:// pavel.bazhanov.pro/translations/chinacivillaw/china_company_registration_regulation_statut/. 
PRC Act "On Foreign Trade"13 adopted in 1994 played an important role in the further development of a market economy. The Act stipulated key rules relating to the access of companies to foreign trade activity, export and import of products, technologies, international trade in services, protection of intellectual property rights, foreign trade investigations, foreign trade assistance, and legal protection measures and also stipulated legal liability for foreign trade offenses. ${ }^{14}$

Legislation improvement measures to create and improve Chinese market mechanisms for the economy were taken between 1987 and 1994. But the anticipated accession failed, mainly due to the unwillingness of United States to grant China developing country status in the WTO. The growth of Chinese products exports in the early 1990s alarmed American business leaders, who were extremely angry with the violations of intellectual property rights in the People's Republic of China.

According to the United States International Trade Commission, 2009 report, in the U.S. the biggest losses from illegal intellectual property use were found in the copyright area: from $\$ 10.2$ to $\$ 37.3$ billion; furthermore, illegal use of trademarks: $\$ 1.4$ to $\$ 12.5$ billion. From $\$ 0.2$ to $\$ 2.8$ billion was lost from illegal use of patents; from $\$ 0.2$ to $\$ 2.4$ billion was lost from misappropriation of trade secrets. ${ }^{15}$

Violation of intellectual property rights is still widespread in China despite the best efforts of the government. In addition, China signed the Agreement on TradeRelated Aspects of Intellectual Property Rights (TRIPs Agreement); furthermore, the PRC is a party to all major international agreements in the field of intellectual property (Paris Convention for Protection of Industrial Property since 1985, Madrid Agreement Concerning the International Registration of Marks since 1989, Berne Convention for the Protection of Literary and Artistic Works since 1992, the Protocol Relating to the Madrid Agreement since 1995, and the World Intellectual Property Organization Copyright Treaty since 2007).

The acute need for improving intellectual property rights protection mechanisms in China led to the necessity of improving the quality of this sector's legal regulation at the national level. A number of laws of the PRC have been adopted in this area, namely on trademarks (1982, as amended in 1993, 2001 and 2013), on patents (1984, as amended in 1992, 2000 and 2008) and on copyright (1990, as amended in 2001 and 2010).

Legal regulation of copyright and related rights in China is also carried out on the sub-legislative level. There are the regulations of the State Council of the $\mathrm{PRC}^{16}$ and

13 PRC Act "On Foreign Trade" adopted at the Seventh Session of the Permanent Council of the National People's Congress of the $8^{\text {th }}$ Convocation held on May 12, 1994 and amended by Decision taken at the Eighth Session of the Permanent Council of the National People's Congress of the $19^{\text {th }}$ Convocation held on April 6, 2004 (Feb. 25, 2017), available at http://chinalawinfo.ru/economic_law/law_foreign_trade.

14 Id.

15 Available at http://trade.ec.europa.eu/doclib/docs/2013/april/tradoc_146029.pdf.

16 "On Application of the Trademark Law of the PRC" (State Council of the PRC Decree No. 651, as amended in 2014). 
departmental acts of the Main State Directorate of the Administration for Industry and Commerce of China, the State Administration for Intellectual Property of China, and others. ${ }^{17}$

An important role in ensuring the protection of copyright is played by the explanations of the Supreme People's Court of China that are devoted to consideration of civil and administrative cases dealing with patents. They are as follows: Provisions of the Supreme People's Court of China on Several Issues of Application of Law when Considering Patent Litigations, Explanation of the Supreme People's Court of China on Several Issues of Application of Law in Patent Infringement Litigations, and Several Provisions of the Supreme People's Court of China on Application of Legislation in Stopping Patent Rights Violations before Commencing a Suit.

There is also the Explanation of the Supreme People's Court of China on Several Issues of Application of Law in Civil Suits Dealing with Well-Known Trademarks. This explanation clarifies the rules for application of the Law of the PRC on Trademarks and Regulations on Recognition and Protection of Well-Known Trademarks by the people's courts. The Explanation of the Supreme People's Court of China on Issues of Legislation and Jurisdiction Limits in Trademark Cases clarifies the rules of jurisdiction in respect of trademark-related lawsuits, and it contains some rules of application of the Law of the PRC on Trademarks in connection with the amendments of 2001.

It should be noted that while reforming economic legislation, legislation in the sphere of intellectual property rights protection and establishing new institutions, China was seeking collaboration with the WTO and at the same time creating a model of "governing in harmony with multilateral institutions" to achieve its national development objectives.

The period from 1995 to 2001 was the final stage of the negotiation process, a dynamic period in China's path to accession to the WTO. It was during this period of time that GATT transformed into the WTO; also, China's negotiations, now with the WTO, became more complicated. The difficulty in the negotiation process centered around the main question, On what terms will China join the WTO? That is to say, is China a developed or developing country? The answer remained unresolved. Western countries led by the United States were of the common mind that China should not be given the exclusive right of preferential status of a developing country in contravention of provisions of WTO agreements. The position of the United

17 Regulations on Recognition and Protection of Well-Known Trademarks dated July 3, 2014, Regulations on Registration and Regulation of Collective and Certification Trademarks dated April 17, 2003, Trademark Testing and Trademark Review Standards dated December 31, 2005, Trademark Review Rules as amended on May 28, 2014, Regulations on Trademark Essence Verification as of February 8, 2007, Regulations on Application of the Copyright Law of the PRC (State Council of PRC Decree No. 633, in force since March 1, 2013), Regulations on Collective Management of Copyright (State Council Decree No. 429, in force since March 1, 2005), as well as departmental acts of the State General Administration of Press, Publication, Radio, Film and Television of China (National Copyright Administration of the PRC before 2013). 
States and Western countries was justified by the fact that if admitted to the WTO as a developing country, China would exert influence from inside the organization on global economic processes in favor of the "third world" and its own national interests.

But China continued to insist on developing country status in terms of the agreements of the Uruguay Round of multilateral trade negotiations. At this stage, Chinese negotiation tactics changed: China took up a wait-and-see attitude. As a result, the matter was resolved in China's favor - its admission to the WTO would be with developing country status.

Accepted as a developing country, and under the corresponding provisions of the agreements, as a WTO member China not only received brand new powers, but also retained the reformed previous powers of a global business entity. Among them, it is important to highlight:

- The right to a three-five year transition period for a step-by-step opening of its domestic market, decreasing of import duties, continuation and energizing of overall market reforms;

- Full membership in WTO agreements, which allows, among other actions, to increase exports;

- The right of a developing country to subsidies at the rate of 8.5 percent of product value;

- The right to subsidies for overall domestic production not aimed at export (under the arrangements of agreements with the WTO);

- The right to preserve the system of state trading, including the government's right to price key products;

- The right to preserve limits while opening the service industry to foreign capital;

- The right to export duties for more than 80 groups of products involving protection of national resources of the People's Republic of China;

- The right to exercise quality check of import and export outputs;

- The right to protect and raise above market competition levels branches of the national economy connected with national security and thereby not open to foreign capital (defense industry, publishing, film industry, etc.).

Accession negotiations became active again after Chinese-American relations warmed and the exchange of visits of U.S. and PRC presidents in 1997-1998. An important factor in the revival of the negotiations process of that time was the highpowered lobbying of the U.S. Congress by American business leaders involved in business operations in the Chinese domestic market.

Following the signing of the agreement with the United States in 1999, one of the still unsettled matters pertained to permanent, most-favored nation treatment (MFNT) for the PRC. The United States did not intend to automatically extend MFNT to the PRC in trade even after its accession to the WTO. The United States advocated 
the idea of keeping the Jackson-Vanik Amendment to the U.S. Act "On Trade" of 1974 in force. In any event, the problem was resolved in the favor of China. Later, a bilateral agreement between China and the European Union was signed, in May 2001. In December of that year China was admitted to the WTO as a full member.

The fourth period (1995-2001) in China's process of accession to the WTO had the particularities of legal support of Chinese economic development. First of all, national legislation was vigorously updated. Previously adopted laws were further detailed by regulations. A number of rules and regulations appeared in 1995, some of which are listed below.

"Detailed Rules of Application of PRC Act 'On Cooperation Joint Ventures of Chinese and Foreign Capital"' clarified some provisions of PRC Act "On Cooperation Joint Ventures of Chinese and Foreign Capital."These rules related to elaboration of procedures on the establishment and liquidation of cooperation in joint ventures, payment of contributions, arrangement of management bodies of joint ventures, and procedures of profit distribution among members. ${ }^{18}$

Temporary Directions "On Some Matters of Establishment of Joint-Stock Limited Liability Companies with Foreign Capital" adopted by the PRC Ministry of Foreign Trade and Economic Cooperation (today, the PRC Ministry of Commerce) determined requirements for newly established joint-stock companies with foreign capital and procedures of transformation of existing companies into joint-stock companies with foreign capital. ${ }^{19}$

Temporary rules "On Regulation of Representation of Foreign Accounting Companies" adopted by the PRC Ministry of Finance in 1996 (still in force) defined the procedures for the establishment of representative offices of foreign accounting companies (including accounting companies with origins in Hong Kong, Macao, and Taiwan). ${ }^{20}$

Some Directions "On Change of Share Participation of Members of Companies with Foreign Capital" were adopted in 1997 to clarify rules of registration of changes in allocation of interests to members of companies with foreign capital. ${ }^{21}$

18 Detailed rules of application of PRC Act "On Cooperation Joint Ventures of Chinese and Foreign Capital" (2005) (Feb. 25, 2017), available at http://pavel.bazhanov.pro/translations/chinaeconomiclaw/ china_sino-foreign_cooperation_enterprise_law_implementation/.

19 Temporary Directions “On Some Aspects of Establishment of Joint-Stock Limited Liability Companies with Foreign Capital" adopted in 1995 by the PRC Ministry of Foreign Trade and Economic Cooperation (Feb. 25, 2017), available at http://pavel.bazhanov.pro/translations/chinaeconomiclaw/china_foreigninvested_joint_stock_companies/.

20 Temporary Directions "On Regulation of Representation of Foreign Accounting Companies" adopted in 1996 by the PRC Ministry of Finance (Feb. 25, 2017), available at http://pavel.bazhanov.pro/translations/ china_accounting/china_foreign_accounting_firms_representative_offices/.

21 Some Directions "On Change of Share Participation of Members of Companies with Foreign Capital" adopted in 1997 (Feb. 25, 2017), available at http://pavel.bazhanov.pro/translations/chinaeconomiclaw/ china_foreign invested_enterprise_equity_change/. 
PRC Act "On Contracts" dated March 15, 199922 seems to be the most important for economic modernization. It became a principal Act governing the conclusion of contracts in the PRC between equal civil law subjects. Act "On Contracts" determined key principles of contractual law, general provisions for conclusion, execution and termination of contracts, and specific rules referring to several types of contracts. ${ }^{23}$ The Act was adopted to protect the legal interests of contractual parties for such contracts so as not to affect the social or economic situation in the country and to promote social cohesion and modernization. ${ }^{24}$

Furthermore, in 2000 the "List of Priority Branches for Foreign Investments in Western and Central Regions" was first elaborated. The List defined the types of activities where foreign investments are encouraged in the western and central regions of the country. ${ }^{25}$

\section{System of China's "Economic" Law}

It should be pointed out that the change of legislation is one of the directions of structural reform of the economy at any stage of national development. Legal support of economic reforms should be documented by laws and regulations. The content of legal acts reflects the search for optimal models of modernization of the economy in order to introduce an open economic order. Rules that govern titles, competition, money turnover, finances, taxes, foreign economic activity, etc. are reflected in legal forms and enforced by legal instruments. Thus, enlargement of the basis for economic growth poses a governmental challenge related to the improvement of the quality of legal regulation of the economy.

Economic legislation of China includes different types of legal acts. ${ }^{26}$

1. PRC Organic Law.

2. Acts (laws and other acts adopted by the National People's Congress and the Permanent Council of the National People's Congress). For example: General

22 PRC Act "On Contracts" adopted at the Second Session of the National People's Congress of the $9^{\text {th }}$ Convocation held on March 15, 1999 (Feb. 25, 2017), available at http://chinalawinfo.ru/civil_law/ law_contract.

23 Id.

24 Современное право Китайской Народной Республики (обзор законодательства 1978-2010 гг.). Часть 1: 1978-2001 гг. [Contemporary Law of the People's Republic of China (Legislation Review 19782010). Part 1: 1978-2001] (Moscow: IFES RAS, 2012) (Feb. 25, 2017), also available at http://istina.msu. ru/media/publications/book/97d/49d/3401367/SV_Pravo_KNR_ch.1_2012..pdf.

25 The 2013 edition of this document is in force (Feb. 25, 2017), available at http://pavel.bazhanov.pro/ translations/chinaeconomiclaw/china_western_central_regions_foreign_investment_encouraged_ industries_catalogue/.

26 Information on examples of legal and regulatory economic acts of the PRC was obtained from Pavel Bazanov's website (Feb. 25, 2017), available at http://pavel.bazhanov.pro/translations/ chinalaw_list/. 
provisions of PRC Civil Law, PRC Civil Code/PRC Act "On Civil Process," PRC Act "On the Struggle against Unfair Competition" (1993), etc.; Decision of the Permanent Council of the National People's Congress "On Creation of Intellectual Rights Courts in Beijing, Shanghai and Guangzhou."

3. State Council Acts (Acts of the Central People's Government). For example: "List of Investment Projects approved by the Government" (2014); Direction "On Application of PRC Act on Joint Chinese and Foreign Companies Limited by Shares" (1983, edition 2014); Temporary Direction "On Value Added Tax" (1994, edition 2008); Provision "On Control of Foreign Investments Distribution" adopted by PRC State Council (2002); "Detailed rules of application of PRC Act on Cooperation Joint Ventures of Chinese and Foreign Capital" (1995); "Rules of Partnerships Registration" (edition 2007); "Project of Arbitration Institutions Rearrangement" (1995); Some recommendations of PRC State Council "On Further Performance of Works on Use of Foreign Investments" (2010); Notification of Chancellery of PRC State Council "On Creation of System of Safety Control of Consolidations and Mergers of Chinese Companies by Foreign Investors" (2011).

4. Official Acts (regulatory acts of ministries and agencies of the PRC State Council). For example:"List of Branches for Foreign Investments"(2015); Direction “On Registration of Authorized Capital of Companies" (2014); Temporary Direction "On Duration of Joint Companies Limited by Shares of Chinese and Foreign Capital" (1990); Some Directions "On Change of Share Participation of Members of Companies with Foreign Capital" (1997); "Rules of Invoices Regulation" (adopted by Central State Tax Office of the PRC (CSTO PRC)) and Detailed rules of Application of "Rules of Invoice Regulation" (2013); Temporary customs rules on "Regulation of Companies' Solvency" (adopted by Central Customs Office of the PRC (CCO PRC), 2014); Detailed rules of Regulation of State Trade upon Import of Crude Oil, Oil Products and Fertilizers; Notification of PRC Ministry of Public Security and State Office of PRC Commerce and Industry Administration "On Prohibition of Establishing of Debt Collecting Companies."

5. Judicial interpretations (interpretations of the Supreme People's Court and the Supreme People's Prosecutor's Office). For example: Direction of the Supreme People's Court "On Some Aspects of Administrative Hearings in Foreign Trade"; Some Directions of the Supreme People's Court "On Limitation of High Consumer Expenses of Debtors" (2010, edition 2015); Interpretation of the Supreme People's Court "On Limits of Enforcement of Law and Jurisdiction upon Hearing of Trademarks Cases" (2001); Recommendations of the Supreme People's Court "On Equal Legal Protection of Non-governmental Economy for Assistance in Sound Development of Nongovernmental Economy" (No. 27-2014); Notification of the Supreme People's Court "On Some Matters of Enforcement of Arbitration Decisions Issued in Hong Kong" (Notification No. 415-2009).

It should be noted that a distinctive feature of legal regulation in the PRC is the existence of a specific source of law - rules set by the Supreme People's Court. This is related to the arrangement of government authority in which there is no separation 
of powers among the legislative, executive, and judicial branches. Together with other branches of power, the judicial branch in China can also give interpretations in addition to delivery of justice. In the years of Chinese membership in the WTO, judicial practice related to the protection of intellectual property rights constantly has improved. The legislative activity of the Supreme People's Court allows the determination of the direction of development of law enforcement practice in the most important fields of government control.

6. International agreements (international agreements and contracts concluded by China with Russia and agreements between the PRC and the Specific Administrative District Hong Kong, Specific Administrative District Macao and Taiwan). For example: Agreement between the People's Republic of China (PRC) and the Specific Administrative District Hong Kong (SAD Hong Kong, Xianggang) on Close Economic Partnership (2003).

We can see that since preparations for accession to the WTO and even today Chinese legislation includes several categories and many legal acts; legislation includes both laws and regulations. Different spheres of economic activity of the country have received the attention of specific legal regulation.

As a rule, regulations ensure government control of a specific sphere of the economy and generally are adopted following enactment of a law. Thus, PRC Act "On Joint Chinese and Foreign Companies Limited by Shares" was adopted at the Second Session of the NPC of the $5^{\text {th }}$ Convocation held on July 1, 1979. Within four years (1983), to ensure successful application of this Act, Norms and Rules on application of PRC Act "On Joint Chinese and Foreign Companies Limited by Shares" was adopted.

Directions, rules, recommendations, notifications, etc. contain procedures on the registration of joint ventures, arrangement of corporate management, land use, and so forth. Thus, legal regulation leads to elaboration and adoption of a rule or regulation that ensures implementation arrangements. For example, after PRC Act "On Partnerships" (1997) was adopted, Regulation Measures for establishing partnerships in the PRC by foreign companies and natural persons (2010) were elaborated; and Customs Code/PRC Customs Law (1987) was followed by adoption of Norms and Rules "On Customs Protection of Intellectual Property Rights" (2003).

A different lawmaking strategy is applied to tax relations where an advance regulation is used. First, regulations (temporary norms and rules/temporary directions) are adopted for an indefinite period of time. Many temporary norms and rules adopted in different periods of time are still in force in the PRC: Temporary PRC Norms and Rules "On Natural Resources Use Tax" (1994), "On Urban and Urban District Lands Tax" (1988), "On Property Assignment Tax" (1997), etc. The application of such norms and acts is then analyzed. Following analysis, the regulation either becomes a law or not. ${ }^{27}$ This particularity of legal regulation of tax relations allows

27 Севальнев В.В. Правовое регулирование налогообложения инновационного сектора КHР: Автореф. дис. ... канд. юрид. наук [Sevalnev V.V. Legal Regulation of Taxation and Innovation Sector of the PRC: Abstract of PhD Thesis] 12 (Moscow, 2012). 
the Chinese lawmaker to make the domestic laws more stable, and thus the legal norm in this case is the result of law enforcement practice approbation.

It is necessary to highlight the positive dynamics of Chinese legislation based on specifics of regulated spheres and deep analysis of existing norms. In the last stage of negotiations on the accession of the PRC to the WTO (the second half of the 1990s - early 2000s), the tax system was reformed and measures on encouraging foreign investments were taken. This was accompanied by important laws and directions "On Speedup of Technical Progress," "On Stimulation of Technological Solutions Implementation," "On Stimulation of Small- and Medium-sized Business," "Rules for State Bonuses Award in Technological Sphere," a set of measures related to implementation of the "Government Program of Middle-term and Long-term Development of Science and Technology for 2006-2020."

A national legislation alignment process was activated beginning in the early $2000 \mathrm{~s}^{28}$ The harmonization of the use of economic and legal instruments for Chinese and foreign companies was continued. And the influence of WTO norms on Chinese national legislation became obvious. It was WTO accession that determined the necessity of implementation of the organization's requirements into economic activity in the PRC. Thus, China elaborated the legal support of industry, trade, innovative activities, and attraction of foreign investors ("On Value Added Tax Charged from Companies with Foreign Investments and Foreign Companies," PRC Act "On Contracts" 1999, Currency Control norms and rules, etc.).

\section{Conclusion}

The contemporary political situation is changing. Economic sanctions now have political origin. New priority directions of national security defined in January 2015 by the Central Politburo of the Communist Party of China require constant improvement of economic and legal instruments. Analysis of legislation shows the steady motion of China to market economy development. Alignment of national economic legislation with WTO requirements allows China's entrance into the unified legal space of foreign economic activity.

Side by side with WTO obligations accepted by China we can highlight harmonization of national legislation with international norms of market economy countries, and China has implemented them regularly. Furthermore, in terms of China's admission to the WTO, legislation and delivery of justice had to be reformed. The necessity of reforms was justified by improvement in transparency, unification of application of Chinese legal rules and the judicial review process. ${ }^{29}$

28 Jizeng Fan, Constitutional Transplant in the People's Republic of China: The Influence of the Soviet Model and Challenges in the Globalization Era, 2(1) BRICS Law Journal 50-99 (2015).

29 Karen Halverson, China's WTO Accession: Economic, Legal, and Political Implications, 27(2) Boston College International \& Comparative Law Review (2004) (Feb. 25, 2017), also available at http:// lawdigitalcommons.bc.edu/iclr/vol27/iss2/6. 
In this way, the Chinese experience of many years, from 1982 to 2001, to accession to the WTO passed through several stages. China did its best over the course of this time to get the most advantageous developing country member status in the WTO.

Despite stringent requirements and opposition during the negotiations on China's accession to the WTO, China made good use of the WTO's economic area resources in its own interests and created a relatively stable legal base for market relations development. It should be mentioned that China has learned how to use WTO legal instruments for the realization of its own national interests. For instance, in 2011 Chinese lawyers proved through the use of the WTO legal framework that the United States subsidized chicken output production. As a result, Beijing interdicted imports of this output from the United States to China, in strict accordance with WTO rules. The reality is that colossal correction work was conducted by China in order to bring Chinese legislation into line with WTO rules. On the whole, 1,400 laws were passed, 559 repealed, and 197 legal acts amended.

In order to carry out China's obligations as a member of the WTO, domestic administrative legal instruments and rules needed amendment. In twenty-five departments and state committees belonging to the Chinese State Council, in provinces, independent areas, and in cities of central submission a centralized check of laws and regulations was conducted.

In the Chinese experience we are able to see how strengthening the role of market legislation can change the model of state governing. New legal acts promoted change in the work of the Chinese government towards an increase in its efficiency. By reforming its economic legislation China has taken significant steps towards the development of market legislation and market economy.

Thus, this study concludes that the People's Republic of China managed to create a stable legal basis for the development of market relations in the state after admission to the WTO. Approximation of Chinese economic laws and the legal rules of the WTO was accomplished by means of three actions: implementation of WTO rules into Chinese legislation; references to WTO norms; and the presence of legal acts, which do not conflict with WTO rules. Economic legislation was the first to transform as Chinese companies needed protection of their rights and interests after entering into the international market.

We distinguish three major legal acts that influenced the development of foreign trade and foreign economic relations of China most of all after joining the WTO. Firstly, the 1994 law on foreign trade determined major rules of foreign trade for Chinese companies. Secondly, the Chinese law on enterprises backed by foreign capital stimulated the development of the Chinese market economy, and foreign economic and technical collaboration with foreign enterprises. Thirdly, the 1987 Customs Code determined and settled significant aspects of the modernization of Chinese economic development, including the necessity"to assist foreign economy connections and trade, scientific, technical and cultural exchange.".30

30 PRC Customs Code, supra note 6. 
When the reforms of Chinese legislation took place it is important to take into account that WTO regulations had already become a part of Chinese national laws, which regulated foreign trade, investment, agriculture, the protection of Chinese companies, equalization of their rights and conditions when entering foreign markets, etc. WTO rules were implemented into national Chinese legislation to set up a united legal space for foreign trade relations. Taking into consideration the economic and legal measures undertaken by China and the results obtained afterwards, we can assume that China's entrance into the WTO was successful. And considering a number of similar geopolitical and economic characteristics, we can also designate these measures as useful for study and use in Russia.

\section{References}

Fan J. Constitutional Transplant in the People's Republic of China: The Influence of the Soviet Model and Challenges in the Globalization Era, 2(1) BRICS Law Journal (2015).

Halverson K. China's WTO Accession: Economic, Legal, and Political Implications, 27(2) Boston College International \& Comparative Law Review (2004) (Feb. 25, 2017), also available at http://lawdigitalcommons.bc.edu/iclr/vol27/iss2/6.

Wei L. China's WTO Negotiation Process and Its Implications, 11(33) Journal of Contemporary China (2002)

\section{Information about the authors}

Irina Mikheeva (Nizhny Novgorod, Russia) - Head of the Department of Constitutional and Administrative Law, National Research University Higher School of Economics (25/12 Bolshaya Pecherskaya St., Nizhniy Novgorod, 603155, Russia; e-mail: imikheeva@hse.ru).

Anastasia Loginova (Nizhny Novgorod, Russia) - Associate Professor of the Department of Constitutional and Administrative Law, National Research University Higher School of Economics (25/12 Bolshaya Pecherskaya St., Nizhniy Novgorod, 603155, Russia; e-mail: aloginova@hse.ru). 